OVIO OLARU

\title{
DETECTIVE FICTION IN THE EAST ${ }^{1}$
}

The detective novel, albeit not being a literary phenomenon with a long Romanian tradition, is regarded as fundamental for western popular culture, not only because of its outstanding tradition in the USA and in Western Europe, but also thanks to the various ideological stances it was imbued with and embodied throughout the years. A critical component of the $19^{\text {th }}$ century feuilletonistic period, the stories of detection were one of the first instances of commercial literature that have permeated the public sphere, ultimately becoming the very embodiment, within the sociology of literature, of the democratization of literature, as its evolution unfolded simultaneously to the increase of literacy among the lower social strata. The literacy rates of late $18^{\text {th }}$ century Europe, although higher than in the rest of the world, enabled only a fraction of the continent's population to enjoy reading literature. By 1820 , the United Kingdom had a $53 \%$ literacy rate at a population of 16.2 million, whereas Sweden had the highest literacy rate of $75 \%$ at a population of approximately 2.59 million. France, although scoring lower than both, had a $38 \%$ literacy rate and a population of 31.5 million. This means that a little over 8 million people could read in the first two decades of $19^{\text {th }}$ century Britain, while nearly 12 million people in France were literate at that time. By 1870, 76\% of Britons and 69\% of Frenchmen were literate, while the world literacy rate still lingered at $19 \%$. We are looking at a near $20 \%$ increase in the literacy rates of Great Britain and a staggering 31\% increase in France over the span of 50 years. In the case of the $20^{\text {th }}$ century, it is perhaps relevant that in Great Britain alone, the number of published books increased exponentially, from 9.000 titles in 1914 to 14.000 titles published in 1939. However, the increase is most visible when seen against the increase in the number of books hosted by public libraries. In 1911, British public libraries contained 54 million books; by 1939, that number had reached over 247 million copies.

Franco Moretti, in his 2000 "The Slaughterhouse of Literature", addresses the emergence of detective fiction against the backdrop of the broader evolution of commercial literature towards the end of $19^{\text {th }}$ century Britain. He argues that the formal narrative component that succeeded in transforming sensational literature into detective fiction proper was the instrument of the "clue". In the

\footnotetext{
${ }^{1}$ This article is a revised and extended version of a paper presented at the International Conference „Zilele Sextil Pușcariu” (12-13 September 2019) and published, in Romanian, in the conference proceedings (Caietele Sextil Puscariu, 2019, 4, pp. 475-482). This is the first internationally available rendition.

${ }^{2}$ Franco Moretti, “The Slaughterhouse of Literature”, Modern Language Quarterly, 61, 2000, 1, pp. 207-227.
} 
"slaughterhouse of literature", to borrow his metaphor, wherein emerging authors viciously fought for the attention of an ever-expanding readership, this was the element that vouchsafed the survival of certain authors to the detriment of other authors through two convergent and complementary processes, "selection and magnification", as he calls them, in the sense "that readers select, and then markets magnify, but only in accordance with the perverse market logic - to those who have, more shall be given - that goes by the name of increasing returns"3. Essentially, if the literature of detection prior to Arthur Conan Doyle was profoundly elitist in its implications, in the sense that the narrative unfolding took place suddenly and unexpectedly, not having been foreshadowed by a series of "clues" that would have allowed the naïve reader to decipher the mystery himself, guiding his footsteps from the suzjet to the fable (according to Viktor Shklovsky's classification), by introducing keys to understanding the process of defamiliarization, the detective narrative after Doyle significantly contributes to the democratization of leisure reading.

Three convergent forces, therefore, transformed detective fiction into one of the most popular narrative forms of the $20^{\text {th }}$ century: the increase in literacy, the automatisation of production coupled by the standardization of the labour day, and the formal democratization of the literary text.

The main lines along which the detective fiction of the $20^{\text {th }}$ century came together as a cohesive genre are the British and the American tradition. The British armchair detective corresponds, in a wider context, to the generic cultural concept of "Britishness": elitist in the language it employs, taking place preponderantly in aristocratic milieus which nevertheless limit themselves to a series of rural-idyllic or domestic environments wherein crime is an absolute exception. Relatively slowpaced in their narrative unfolding, the novels chiefly borrow the form of challenging intellectual puzzles, departing from the - oftentimes aestheticist specificity of their protagonists (Hercule Poirot's dandyism, Miss Marple's warmhearted temper, representing but slightly different versions of Sherlock Holmes' idiosyncrasies). Ideologically, the armchair detective tradition attempts to shine light on the underbelly of a presumably morally degraded world, but which nonetheless conserves the guise of nobility, and through this uncover its hypocrisy.

The American tradition of the hardboiled, on the other hand, departs from the urban agglomerations of America: urbanized milieus massively borrowing from the angst and noir of German expressionism (an influence that becomes obvious in the genre's cinematographic adaptations), engaging heteronormative, hypermasculinized, overly qualified and morally incorruptible heroes. A man capable of intuition and wit, displaying physical force as well as unusual empathy, the hardboiled hero becomes a perfect narrative instrument, ready to handle and

\footnotetext{
${ }^{3}$ Franco Moretti, Distant Reading, London - New York, Verso, 2013, p. 146.
} 
resolve an infinite number of possible narrative permutations, not least because of his universality:

$\mathrm{He}$ is the hero; he is everything. He must be a complete man and a common man and yet an unusual man. He must be, to use a rather weathered phrase, a man of honor by instinct, by inevitability, without thought of it, and certainly without saying it. He must be the best man in his world and a good enough man for any world. I do not care much about his private life; he is neither a eunuch nor a satyr; I think he might seduce a duchess and I am quite sure he would not spoil a virgin; if he is a man of honor in one thing, he is that in all things. He is a relatively poor man, or he would not be a detective at all. He is a common man or he could not go among common people. He has a sense of character, or he would not know his job. He will take no man's money dishonestly and no man's insolence without a due and dispassionate revenge. He is a lonely man and his pride is that you will treat him as a proud man or be very sorry you ever saw him. He talks as the man of his age talks - that is, with rude wit, a lively sense of the grotesque, a disgust for sham, and a contempt for pettiness. The story is this man's adventure in search of a hidden truth, and it would be no adventure if it did not happen to a man fit for adventure. He has a range of awareness that startles you, but it belongs to him by right, because it belongs to the world he lives in. If there were enough like him, the world would be a very safe place to live in, without becoming too dull to be worth living in ${ }^{4}$.

A hero that "resists the official, but not quite legitimate, authority of a decadent society, now elevated into the towering bureaucratic impersonality of the law" and by whose presence the hardboiled novel succeeds in fulfilling two functions at the same time: first, that of bringing attention to the presumed moral decay of American society, presented as an ubiquitous and ever-worsening state, and second, that of emphasizing the pragmatism, matter-of-factly approach of the generic American hero, whose features will lie at the heart of later heroic representations, especially in the action film.

At the intersection of these two very specific subgenres a third one takes shape, that of the police procedural, which, as its name suggests, attempts to objectively depict police work in all its tediousness and unspectacular evolution. By eliminating the dominance of a single crime-solving agent, choosing to employ neither the dynamic and straightforward "lone detective", nor the charismatic and sometimes peculiar "armchair detective", the police procedural makes use of elements hitherto neglected, such as police bureaucracy, interrogations, fieldwork, forensics, and so on.

As for the predilect readership of detective fiction, it remains uncontested that it represented one of the most prolific segments of commercial literature during the $20^{\text {th }}$ century, if not the most read genre altogether. The massive popularity of

\footnotetext{
${ }^{4}$ Raymond Chandler, The Simple Art of Murder, Boston, Houghton Mifflin, 1950, p. 19.

5 Sean McCain, "The Hard-Boiled Novel", in Catherine Ross Nickerson (ed.), The Cambridge Companion to American Crime Fiction, Cambridge, Cambridge University Press, 2010, p. 45.
} 
paperback books, which increased exponentially during the 1930s with the founding of the Penguin publishing house, was preceded only by the proliferation of "penny dreadfuls" or "tuppenny books" during the $19^{\text {th }}$ century. Highbrow literature with a claim on artistic merits, from which the entire literary canon of the $20^{\text {th }}$ chose its most representative works, was printed, up until the late 1960s, in the form of hardcover copies, whereas the cheaper, dispensable paperbacks were reserved for commercial literature.

In discussing the presence of detective fiction in the communist East, I depart from a series of claims and observations conducted by the Russian-born scholar Andrew Baruch Wachtel, who in his 2006 Remaining Relevant after Communism, noted that "communist governments for the most part suppressed such Western literary genres as detective novels, thrillers, horror novels, fantasy and romance on the grounds that literary work of this kind could not play a positive role in nurturing communist society" and that "in Eastern Europe, at least until the collapse of communism, popular or pulp literature was for the most part nonexistent, and serious nonfiction was rare" 7 .

Therefore, the novelistic genres and subgenres originating in the Western, capitalist tradition are not to be regarded as innocent cultural products, but as laden with the ideological background of the regime in which they emerged. Even if the import of these literary forms would not have had the projected corrupting effect anticipated by the communist authorities, Wachtel claims, their refusal is categorical and political in nature. Corollary to this refusal of foreign import, argues Wachtel, "Eastern Europe is that part of the world where serious literature and those who produce it have traditionally been overvalued" 8 , meaning that, far from being the sole consequence of communist cultural paternalism, the absence of a proper popular literature is the result of the massive symbolic capital of "serious literature", designating literary production that fulfils the criteria of "the autonomy of the aesthetic". The classical whodunit, initially conceived for a readership selected from the British bourgeoisie, portraying and allowing for the existence of class difference by choosing an aristocratic-idyllic narrative backdrop and a protagonist with intellectual tendencies, clearly divorced from the vicissitudes of Realpolitik, could never be cultivated or encouraged by communist literary institutions. The hardboiled tradition, on the other hand, is regarded as a response to the growing criminality of American society, marked by the absence of a strong state that would counterbalance it through social policies aimed at mending inequality and class tensions. In a society with claims on egalitarianism, such as the socialist one, urban criminality is refused literary expression, not least because

\footnotetext{
${ }^{6}$ Andrew Baruch Wachtel, Remaining Relevant after Communism. The Role of the Writer in Eastern Europe, London - Chicago, The University of Chicago Press, 2006, p. 32.

${ }^{7}$ Ibidem, p. 8.

${ }^{8}$ Ibidem, p. 4.
} 
criminality in itself is tacitly hidden from sight, as it does not even make an appearance through the channels of state media.

What are the causes of this backwardness? The symbolic capital of communist authors, doubled by the policies imposed by the state-run publishing houses, concentrating on the democratization of reading and on the socialist upbringing of the proletariat through unprecedented print runs and massive royalties offered to authors, guaranteed that every book published was an instant bestseller. In a sense, every other novel was massively "popular" even in light of the fact that they could, after being read, become valuable currency in the informal trade market, being exchanged for basic goods such as meat or butter - especially during the last communist decade. Boris Akunin, probably the most popular crime fiction author of contemporary Russia, observed during a 2009 interview given to Radio Free Europe that detective fiction in the Soviet Union existed only in nuce, since crime, according to the party logic, is not possible under triumphant socialism.

The same conclusion can be drawn about the Romanian communist context as well, not least because the book market of the Socialist Republic of Romania mimicked the Soviet one shortly after 1948. On the other hand, Mihai Iovănel claimed in his 2017 Ideologiile literaturii în postcomunismul românesc [The Ideologies of Literature in Romanian Postcommunism] that local detective fiction was abundant during communism, but essentially mediocre ${ }^{9}$. During postcommunism, the same critic argues that Romanian popular literature virtually disappears, replaced, at least during the 1990s, by translations of western commercial literature. Consulting Dicționarul cronologic al romanului tradus in România 1990-2000 [Chronological Dictionary of the Translated Novel in Romania 1990-2000] (DCRT) ${ }^{10}$, we can observe, for instance, that a single American author of romance novels, Sandra Brown, was translated significantly more during this time than entire national literatures, not least because of the inexpensive translation rights when compared to other genres or authors. Even if "the prestige of serious literature declined drastically in the first post-communist decade" 11 , this did not trigger a response on the national book market, weakened by economic liberalization, going through a laborious process of democratizing its institutions and attempting to cater to a precarious population, for which cultural consumption was not a priority.

"Foreign form, local material - and local form"12, the triangular formula used by Franco Moretti to describe the mechanisms of literary import and the way in

\footnotetext{
${ }^{9}$ Mihai Iovănel, Ideologiile literaturii în postcomunismul românesc [The Ideologies of Literature in Romanian Postcommunism], București, Muzeul Literaturii Române, 2017, p. 184.

${ }^{10}$ Dicţionarul cronologic al romanului tradus in Romania 1990-2000 [Chronological Dictionary of the Translated Novel in Romania 1990-2000] (DCRT), Cluj-Napoca, "Sextil Puşcariu" Institute for Linguistics and Literary History, Romanian Academy, 2017.

${ }^{11}$ Andrew Baruch Wachtel, Remaining Relevant after Communism, p. 6.

${ }^{12}$ Franco Moretti, Distant Reading, p. 57.
} 
which literary peripheries found legitimacy through imitating canonical centres designates, in our case, novels that, departing from the most revered literary forms of the western canon and reaching the most marginal and lowbrow novelistic subgenres, mimicked formal elements in the attempt of obtaining equally valuable Eastern European renditions. The tendency that had emerged during the 1990s, as the Romanian book market was dominated by translations, has gained even more momentum, and translations continue to represent the most prolific component of the Romanian literary field; however, the poles of symbolic power within the translation market have shifted, as the Romanian cultural production is now under the strong influence of the European book market not only in regard to its own production, but also under the aspect of translations.

A recent example is illustrative of the peripheral position of the Romanian book market, which translated works belonging to other peripheral cultures only after they were successfully validated by core cultures in the West. For example, Scandinavian Noir, the most recent crime fiction subgenre from Scandinavia - a likewise peripheral cultural region which has become, by way of being validated by core cultures, the locus of Western interest, what Mads Rosendahl Thomsen called "a temporary sub-centre"13 in 2009 and what Dionýz Durišin by 1989 called a "group of a transitory popular direction"14 -, was predictably translated into Romanian only after the authors belonging to the genre acquired bestseller status in Germany - not least because Germany is the most powerful European book market. The Stieg Larsson case is well-known: after becoming an instant bestseller in 2009 in Germany, his writing attracts renewed global interest for detective fiction and especially for Scandinavian crime fiction, something that, in its turn, leads to more and more authors being translated into Romanian starting with $2011^{15}$. It is only after this initial validation in a core culture such as the German one that peripheries engage in two complementary actions meant to counterbalance a presumed cultural backwardness, but which, in fact, consolidate a form of cultural self-colonization:

1. The immediate translation of Scandinavian Noir authors, accelerated by the imperative of keeping pace with Western literary trends, determines the fact that, in

\footnotetext{
13 See Mads Rosendahl Thomsen, Mapping World Literature. International Canonization and Transnational Literatures, New York, Bloomsbury Academic, 2009, p. 35. "the dominant centers that exercise influence over a long period, both by distributing its authors to other cultures and by adopting others nations' authors into their culture through translation and canonization, and the literatures whose contributions to world literature can be confined to a relatively short period of time or to a limited number of authors, but which create important temporal sub-centers of attention in the history of world literature".

${ }^{14}$ Dionýz Durišin, Theory of Interliterary Process. Translated by Jessie Kocmanová and Zdenek Pistek, Bratislava, Bratislava, Slovak Academy of Sciences, 1989, p. 27.

15 Ovio Olaru, Translating Nordic Noir Bestsellers. Towards a Comparative View on German and Romanian Markets, in Maria Sass, Ștefan Baghiu and Vlad Pojoga (eds.), The Culture of Translation in Romania/ Übersetzungskultur und Literaturübersetzen in Rumänien, Berlin, Peter Lang, 2018, p. 238.
} 
the absence of specialized translators from languages as exotic as Swedish, Norwegian, Danish, or Icelandic, authors were, at least initially, translated from the language in which they first entered an international readership and gained notoriety, namely German, English, or French. Because of this, these latter languages are the ones that re-establish themselves as markers of literary quality and as literary languages by definition.

2. Within the local book markets, literary formulas that had proven themselves successful in the West are instantly revered, in the sense that emerging authors quickly import themes, motifs, narrative elements, and even entire worldviews from the novels to which they are granted access, conserving, however, a local specific and narrative voice.

The ever-diminishing popularity of writers of literature, doubled by a canon that has more or less remained unchanged after communism, thus strengthening the preconception that the literary world nearly exclusively belongs to the great classics, enabled a radical segmentation of the Romanian book market, wherein certain publishing houses have eventually dedicated themselves exclusively to hosting commercial productions (Nemira and Herg Benet, for instance), while others have taken on the task of publishing contemporary foreign and Romanian literature (Polirom Publishing House), and a third group are keen on promoting well-known, conservative authors whose publication presents no financial risk (Humanitas).

In regard to the appeal the genre poses for Romanian readerships, I argue that it has a double component, somehow independent from the external pressure exerted by European trends in the book industry. The first component consists of a very strong set of Western aspirations shared among the Romanian middle class. The second regards the communist penchant for "serious literature", so deeply engrained in Romanian culture as to be internalized and acted upon almost unknowingly.

The global cultural strata are an enlarged projection of nearly every nation's cultural stratification, disposed along the general lines of the combined and uneven development, whereby "capitalist forms and relations exist alongside 'archaic forms of economic life' and pre-existing social and class relations" ${ }^{\prime 16}$, a situation that allows for functional illiteracy, for example, to perfectly coexist with the highest academic performances, oftentimes within the same region or city. Contemporary Romanian readers of Scandinavian Noir belong to the welleducated, culturally open-minded strata, for whom the Scandinavian space can exert at least some degree of fascination, derived from the understanding of cultural cues pertaining to Norientalism: one cannot understand the peculiarity of Lisbeth Salander, the epitome of nonconformism, decorating her newly acquired

${ }^{16}$ WReC (Warwick Research Collective), Combined and Uneven Development: Towards a New Theory of World-Literature, Liverpool, Liverpool University Press, 2015, p. 11. 
apartment with IKEA furniture, the distinguishable marker of Swedish middleclass conformity, without oneself being an aspiring member of the middle-class. Moreover, indulging in recreational reading signals class differentiation, since cultural consumption is not stringent in the hierarchy of needs of the average Romanian citizen: given the relatively high cost of books when compared to other, significantly cheaper entertainment alternatives, investing the time and intellectual resources in leisure reading is a clear indicator of middle- to high-income consumers, for whom Scandinavian Noir is as much a reading preference as a status symbol.

In much the same way as Asia and Africa's postcolonial turn has given rise to - in the words of Kwame Anthony Appiah - a "comprador intelligentsia": "a relatively small, Western-style, Western-trained group of writers and thinkers who mediate the trade in cultural commodities of world capitalism at the periphery" 17 , the post-communist intelligentsia of Eastern European cultures gradually became the embodiment of Western aspirations. Westernized by virtue of education - in the sense of sharing the values of their western counterparts without being necessarily trained abroad -, they lack the socio-cultural infrastructure that would allow them to be part of these 'cosmopolitan circuits'. These Western aspirations were doubled by a firm repudiation, in self-colonizing manner, of everything Balkan/ Eastern European, whose corollary was inevitably the fetishization of the "civilized" West to the detriment of the "primitive", "provincial", "corrupt" East ${ }^{18}$.

In this sense, the Scandinavian space could be popular in Eastern Europe not because of a fascination with Norientalism, the cultural hallmark of Scandinavia, but rather because post-communist readerships sense that the Nordic countries represent an even better way of fulfilling their aspirations towards a Western standard of living, in much the same way they had idealized Western Europe before they were granted effective access to it. While Westerners dream about the romantic North, Easterners seek in Scandinavia an untainted version of the West. Without going into further details, this fetishization of the West is also the result of an Occidentalizing discourse ${ }^{19}$ that has become the mainstream in Romanian postcommunist civil society, relying primarily on widely respected conservative "public intellectuals" and whose core values are abstract freedom, Christian morality, medieval Humanism, undiscerning meritocracy, and radical, unnuanced anticommunism. Unsurprisingly, they have been coined "boierii minţii" ["the mind

\footnotetext{
17 Anthony Appiah, In My Father's House: Africa in the Philosophy of Culture, Oxford, Oxford University Press, 1993, p. 129.

${ }^{18}$ Alexander Kiossev, "The Self-Colonizing Metaphor", Atlas of Transformation, 2011, http://monumenttotransformation.org/atlas-of-transformation/html/s/self-colonization/the-selfcolonizing-metaphor-alexander-kiossev.html. Accessed November 25, 2020.

${ }^{19}$ Couze Venn, Occidentalism: Modernity and Subjectivity, London, Sage, 2000.
} 
boyars"] ${ }^{20}$, a denomination that perfectly summarizes their outdated, but unfortunately still very revered, notions of intellectual aristocracy.

The second consideration regards the prestige literature has enjoyed during communism and which it has continued to enjoy during post-communism as well. Commercial literature - and implicitly also Scandinavian Noir - is a commonly read genre in civilized, prosperous European countries, where habits of cultural consumption are not hindered by the urgency of existential needs, but in Eastern Europe, commercial literature is popular inasmuch as it has the appeal of "serious" literature: lengthy books printed on good quality paper, donning carefully designed, sombre and tasteful cover art. In a sense, much of the appeal of the genre owes to the shallowness of its readers, for whom the books extend their purpose even after having been read, as decorative additions to their libraries.

In stark contrast to the Swedish book market, where crime fiction novels are published at different publishing houses addressing different types of readerships, Romanian renditions of the genre have been generally hosted by visible and affluent publishing houses exclusively: certainly, this owes to the fact that they rank among the few that can afford purchasing translation rights. In Sweden, barely 46 percent of crime fiction novels were published by established publishing houses between 2000 and $2010^{21}$, while the others were published by smaller, independent publishers. In Romania, the genre was traditionally imbued with the perceived advantages of high-brow literature, in the sense of conferring cultural capital to its consumers but without posing the same difficulties as traditional literary canon: the intricacies of modernist prose, the in-depth descriptions and painstakingly slow narrative pace cultivated by realism or the antiquated mannerism of romanticism. Post-communist cultures, which in the Soviet Union and in Romania alike have displayed a decade-long "literaturecentrism" 22 , i.e., a climate favouring literature to the detriment of all other forms of cultural production, have therefore allowed for Scandinavian Noir to evolve into a sort of alternative canon, a common platform for the periphery's growing Western aspirations.

\section{BIBLIOGRAPHY}

DCRT - Dicţionarul cronologic al romanului tradus in Romania 1990-2000 [Chronological Dictionary of the Translated Novel in Romania 1990-2000], Cluj-Napoca, "Sextil Puşcariu" Institute for Linguistics and Literary History, Romanian Academy, 2017.

\footnotetext{
${ }^{20}$ Sorin Adam Matei, Boierii minţii: intelectualii români între grupurile de prestigiu şi piaţa liberă a ideilor [The Mind Boyars: Romanian Intellectuals between Status Gropus and the Free market of Ideas], București, Compania, 2004.

${ }^{21}$ Karl Berglund, Deckarboomen under lupp: Statistiska perspektiv på svensk kriminallitteratur 1977-2010, Uppsala, Avdelningen för litteratursociologi, Uppsala universitet, 2012, p. 19.

${ }^{22}$ Andreea Mironescu, “'Worlding' Romanian Literary Studies”, Philologica Jassyensia, 14, 2018, 1, pp. 295-299.
} 
APPIAH, Anthony, In My Father's House: Africa in the Philosophy of Culture, Oxford, Oxford University Press, 1993.

BERGLUND, Karl, Deckarboomen under lupp: Statistiska perspektiv på svensk kriminallitteratur 1977-2010, Upssala, Avdelningen för litteratursociologi, Uppsala universitet, 2012.

CHANDLER, Raymond, The Simple Art of Murder, Boston, Houghton Mifflin, 1950.

ĎURIŠIN, Dionýz, Theory of Interliterary Process. Translated by Jessie Kocmanová and Zdenek Pistek, Bratislava, Slovak Academy of Sciences, 1989.

IOVĂNEL, Mihai, Ideologiile literaturii în postcomunismul românesc [The Ideologies of Literature in Romanian Postcommunism], București, Muzeul Literaturii Române, 2017.

KIOSSEV, Alexander, "The Self-Colonizing Metaphor", Atlas of Transformation, 2011, http://monumenttotransformation.org/atlas-of-transformation/html/s/self-colonization/the-selfcolonizing-metaphor-alexander-kiossev.html. Accessed November 25, 2020.

MATEI, Sorin Adam, Boierii minţii: intelectualii români între grupurile de prestigiu şi piaţa liberă a ideilor [The Mind Boyars: Romanian Intellectuals between Status Gropus and the Free market of Ideas], București, Compania, 2004.

MCCAIN, Sean, The Hard-Boiled Novel, in Catherine Ross Nickerson (ed.), The Cambridge Companion to American Crime Fiction, Cambridge, Cambridge University Press, 2010, pp. 42-58.

MIRONESCU, Andreea, “'Worlding' Romanian Literary Studies”, Philologica Jassyensia, 14, 2018, 1, pp. 295-299.

MORETTI, Franco, "The Slaughterhouse of Literature", Modern Language Quarterly, 61, 2000, 1, pp. 207-227.

MORETTI, Franco, Distant Reading, London - New York, Verso, 2013.

OLARU, Ovio, Translating Nordic Noir Bestsellers. Towards a Comparative View on German and Romanian Markets, in Maria Sass, Stefan Baghiu and Vlad Pojoga (eds.), The Culture of Translation in Romania/ Übersetzungskultur und Literaturübersetzen in Rumänien, Berlin, Peter Lang, 2018, pp. 231-241.

THOMSEN, Mads Rosendahl, Mapping World Literature. International canonization and transnational literatures, New York, Bloomsbury Academic, 2009.

VENN, Couze, Occidentalism: Modernity and Subjectivity, London, Sage, 2000.

WACHTEL, Andrew Baruch, Remaining Relevant after Communism. The Role of the Writer in Eastern Europe, London - Chicago, The University of Chicago Press, 2006.

WReC (Warwick Research Collective), Combined and Uneven Development: Towards a New Theory of World-Literature, Liverpool, Liverpool University Press, 2015.

\section{DETECTIVE FICTION IN THE EAST (Abstract)}

This study aims to shed light on some of the reasons behind the relative undersupply of crime fiction during communism. The article departs from the commercial nature of crime fiction and exposes the way in which its proliferation corresponded, in Western Europe, to the exponential increase in literacy at the end of the 19th century. Further on, the text addresses the mechanisms that dominated the Romanian publishing industry during the communist regime and how the paternalistic control exerted by the state apparatus virtually eliminated both translated crime fiction, as well as local renditions of foreign plots, whose ideological background were deemed incompatible to socialist society. Lastly, the present study focuses on post-communist evolutions in the book market, especially with respect to popular literature, whose import to East and Central-European countries reveals crucial contemporary cultural hierarchies.

Keywords: Scandinavian Noir, crime fiction, Eastern Europe, Romanian book market, (post)communism. 


\section{ROMANUL POLIȚIST. VARIAȚIUNI EST-EUROPENE (Rezumat)}

Acest studiu urmărește să explice producția aparent modestă de literatură polițistă din timpul perioadei comuniste. Articolul pornește de la o serie de argumente privind natura comercială a ficțiunii polițiste și dezvăluie cum proliferarea acestui gen a corespuns, în Europa de Vest a sfârșitului de secol XIX, unei creșteri exponențiale a gradului de alfabetizare al populației, alfabetizare cu care sa aflat în constantă corelație. Un alt aspect discutat vizează mecanismele dominante ale pieței de carte româneşti din timpul regimului comunist şi maniera în care controlul politic a împiedicat atât traducerea literaturii polițiste vestice, cât și emergența unei tradiții detectivistice clasice după model vestic plasate în imediata contemporaneitate, de vreme ce fondul ideologic al literaturii polițiste era considerat incompatibil cu societatea socialistă. $\mathrm{Nu}$ în ultimul rând, articolul urmărește mutația postcomunistă a pieței de carte și cu precădere în ceea ce privește literatura de consum, al cărei import în țările fostului bloc comunist dezvăluie o serie de ierarhii culturale cruciale pentru înțelegerea dezechilibrelor simbolice dintre centru și periferie.

Cuvinte-cheie: Scandinavian Noir, roman polițist, Europa de Est, piața de carte din România, (post)comunism. 